\title{
バレーボール選手における跳躍特性とトレーニング効果に関する 事例的研究
}

\author{
岡野 憲一 1), 2) 九鬼 靖太 ${ }^{1)}$ 秋山 央 ${ }^{3)}$ 谷川 聡 ${ }^{3)}$
}

Kenichi Okano ${ }^{1,2}$, Seita Kuki ${ }^{1}$, Nakaba Akiyama ${ }^{3}$ and Satoru Tanigawa ${ }^{3}$ : A case study of the characteristics of jumping responsible for different training effects in volleyball players. Japan J. Phys, Educ. Hlth. Sport Sci.

\begin{abstract}
This study focused on volleyball spike jump performance. We classified players based on different types of jumping ability and tested the effects of strength training and plyometrics for each type of ability. Players who excelled in their ability to acquire greater impulse (countermovement jump or CMJ type) showed no significant changes in spike jump height with strength training (improvement in maximum muscle strength), but demonstrated a significant improvement in jump height after plyometrics. In contrast, players with outstanding execution of ballistic movement (rebound jump or RJ type) showed a significant improvement in their spike jump height with strength training (an improvement in maximum muscle strength), but a significant loss of jump height after plyometrics. This reveals that the same training program results in players jumping lower or higher, depending on the jump type. When formulating training to improve the jump height of volleyball players, these results suggest that the type of training must be selected based on the individual player's jumping ability.
\end{abstract}

Key words : stretch-shortening cycle, spike jump, counter movement jump, rebound jump, plyometric exercises キーワード：伸張 - 短縮サイクル, スパイクジャンプ, カウンタームーブメントジャンプ, リバウンドジャンプ, プライオメトリクス

\section{I 緒 言}

バレーボール競技において，筋力トレーニング は競技力向上のために欠かすことのできないトレ 一ニング手段として考えられ，トレーニング現場 において実践されている（有賀ほか，2000）。そ の際, 選手それぞれの体力課題や体力特性といっ た個別性の原則に応じたトレーニング処方を行う ことが理想である.しかし，バレーボール競技に 限らず,多くのチームスポーツのトレーニングは, 全員が同一トレーニング手段を行う全体練習が大 部分を占め, 個別性の原則を適用することが難し
いという側面があり（坂井ほか, 2006）, 星川ほ か（2006）は, サッカー競技において, 選手全員 で同一トレーニングを実施することにより，急速 に体力的な成長を遂げる選手と, 全く反応をしな い選手の双方が存在してしまうといったトレーニ ング効果の相違が課題として挙げている.このよ うな課題に直面しながら, 多くの選手や指導者は 科学的な知見を参考にし，これまでの経験や主観 的な感覚をもとに試行錯誤しながらトレーニング に取り組んでいるのが現状である. 競技選手にお けるパフォーマンスの向上を目的としたトレーニ ングにおいて, トレーニング効果を高めるために は, 選手個々の体力要素を構造的に捉えていく必
1）筑波大学大学院人間総合科学研究科 305-8574 茨城県つくば市天王台 1-1-1

2) 帝京平成大学現代ライフ学部 164-8530 東京都中野区中野 4-21-2

3）筑波大学体育系

305-8574 茨城県つくば市天王台 1-1-1 連絡先 岡野憲一
1. Graduate School of Comprehensive Human Sciences, University of Tsukuba 1-1-1 Tennodai, Tsukuba, Ibaraki 305-8574

2. Faculty of Modern Life, Teikyo Heisei University 4-21-2 Nakano, Nakano-ku, Tokyo 164-8530

3. Faculty of Health and Sports Sciences, University of Tsukuba

1-1-1 Tennodai, Tsukuba, Ibaraki 305-8574

Correspondingauthork.okano@thu.ac.jp 
要があると考えられる.

バレーボール競技におけるパフォーマンスのな かで最も代表的なものにスパイクジャンプが挙げ られる。スパイクによる得点は総得点の占める割 合の $60 \%$ と最も大きいと報告されており（浅井, 2001 ; 都沢ほか, 1995), そのスパイクの優劣は ゲームの勝敗を左右するといわれている（都沢・ 塚本，1999). Sheppard et al.（2008）は, ナショ ナルレベルの男子バレーボール選手を対象に，ス パイクジャンプと垂直跳び，デプスジャンプの跳 躍高，スクワット $1 \mathrm{RM}$ およびスクワットジャン プ時の発揮パワーとの関係について検討し，スパ イクジャンプの跳躍高と相関関係が強かったの は，垂直跳びとデプスジャンプの跳躍高であった と報告しており，スパイクジャンプには垂直跳び のようなより大きな力積を獲得する能力と合わせ て，デプスジャンプのようなバリスティックな運 動を遂行する能力も必要であると考えられる。そ の垂直跳びとバリスティックな跳躍運動との相関 関係があまり強くないことから，垂直跳びの遂行 能力とバリスティックな跳躍運動は別の能力を評 価していることが明らかにされている(遠藤ほか, 2007 ；図子・高松 1995).このことは，スパイク ジャンプの跳躍高向上のためには，大きな力積を 発揮する能力とバリスティックな運動を遂行する 能力という，2つの要素を構造的に捉えてそれぞ れの課題を解決していく必要がある.しかし, 個々 のバレーボール選手によって，垂直跳びのような より大きな力積を獲得する能力とデプスジャンプ のようなバリスティックな運動を遂行する能力の 両要素において相対的な優劣が存在している（岡 野ほか，2017）ことから，それに基づき2つのト レーニング課題に対し，どのように継続的にトレ ーニングを進めていくかを検討していく必要があ る.また, トレーニングプログラムを実施する際, この跳躍能力からみたタイプの相違によって, ス パイクジャンプのトレーニング効果にも大きく影 響を及ぼす可能性も考えられる。このように，チ 一ム全体のスパイクジャンプ向上を目的に，選手 個々の跳躍タイプに応じた適切なトレーニング方 法を明確にするためには，跳躍タイプごとにトレ
ーニング効果を検証していく必要がある．このこ とは，個人の特徵を考慮した合理的なトレーニン グを実践する上で，留意しておくべき課題の 1 つ であると考えられる．また，このようなチームス ポーツのトレーニング課題に基づく報告はこれま で見当たらず，個人の体力特性を考慮しながら卜 レーニングの実践的介入の有効性を検証すること は，現場に役立つ知見となると考えられる。

そこで本研究は, バレーボールに打けるスパイ クジャンプというパフォーマンスに着目して，男 子バレーボールチームにおいて，跳躍力向上を目 的としたトレーニングで代表的なウエイトトレー ニングとプライオメトリックエクササイズ（以下 「プライオメトリクス」と略す）の 2 種類のトレ ーニング事例を検証した。跳躍時におけるより大 きな力積を獲得する能力とバリスティックな運動 を遂行する能力の優劣から選手の跳躍タイプを分 類し，それぞれのタイプの選手が同一のトレーニ ングを実施した際の効果をタイプ別に検証するこ とで，選手個々の体力特性に応じた跳躍力向上を 目的としたトレーニング方法を明らかにするため の基礎的知見を得ることを目的とした。

\section{II 方 法}

\section{A. 最大筋力向上を目的としたウエイトトレーニン グの効果に関する跳躍タイプ別検討(課題1)}

\section{1. 対象}

対象者には，実業団バレーボールチームに所属 する成人男子選手 13 名（年齢： $24.7 \pm 2.7$ 歳，身 長: $184.3 \pm 6.2 \mathrm{~cm}$, 体重: $84.4 \pm 12.4 \mathrm{~kg}$ )を用いた. なお，対象者は，これまで 3 年以上，ウエイトト レーニングを経験している選手であった。これら の対象者には，事前に測定の趣旨，内容について 説明を行い，参加者の同意を得た。

\section{2. トレーニング期間および内容}

本研究のトレーニング期間は 6 月中旬から 7 月 下旬までの 8 週間とし，この期間は主に基礎体力 を養成するための一般的準備期であった。 1 回の トレーニング時間は 60-90 分であり, 週 2 回の 頻度で実施した。なお，トレーニングによる適応 
Table1 Weight training program in study 1.

\begin{tabular}{lll}
\hline Exercise & reps/load & set \\
\hline Squat & $3 \mathrm{reps} / 5 \mathrm{RM}$ & $3 \mathrm{set}$ \\
Leg curl & $10 \mathrm{reps} / 10 \mathrm{RM}$ & $3 \mathrm{set}$ \\
Bench press & $3 \mathrm{reps} / 5 \mathrm{RM}$ & $3 \mathrm{set}$ \\
Bent over row & $3 \mathrm{reps} / 5 \mathrm{RM}$ & $3 \mathrm{set}$ \\
Dumbbell shoulder press & 8reps/8RM & $3 \mathrm{set}$ \\
Wrist curl & $10 \mathrm{reps} / 10 \mathrm{RM}$ & $2 \mathrm{set}$ \\
Calf raises & $20 \mathrm{reps} / 20 \mathrm{~kg}$ & $2 \mathrm{set}$ \\
\hline & \multicolumn{2}{c}{ rest: 60-120 }
\end{tabular}

も考慮し，ウエイトトレーニングが 2 日連続にな らないような日程にした。この期間におけるウエ イトトレーニングは，主に最大筋力向上を目的と したプログラムを実施した（表 1)。 ウエイトト レーニングの条件設定にあたっては, 日本トレー ニング指導者協会のガイドライン（有賀，2008） を参考にし，それぞれトレーニング量と強度を設 定した. 負荷設定は RM 法を用い, トレーニン グ効果に応じて, 可能な限り負荷を漸増するよう に指示した. その他に, バレーボールの技術・戦 術練習を週 4 回（1 回 2 時間程度）実施した。

\section{B. バリスティック運動の遂行能力向上を目的と したプライオメトリクスの効果に関する跳躍 タイプ別検討（課題 2)}

\section{1. 対象}

対象者には, 大学バレーボール部に所属する 大学男子選手 14 名（年齢：19.3 \pm 0.8 歳, 身長： $179.4 \pm 6.6 \mathrm{~cm}$, 体重: $74.8 \pm 10.4 \mathrm{~kg}$ ) を用いた。 なお, 対象者は, これまでウエイトトレーニング とプライオメトリクスの経験があり, かつスクワ ット（以下「SQ」と略す）の最大挙上重量が体 重の 1.5 倍以上の選手であった.これらの対象者 には, 事前に測定の趣旨, 内容について説明を行 い, 参加者の同意を得た.

\section{2. トレーニング期間および内容}

本研究のトレーニング期間は春と秋に行われる 大会（リーグ戦）の中間時期にあたる試合準備期 の 8 週間とした. 本研究の主となるトレーニング 種目はデプスジャンプ（以下「DJ」と略す）で あった. ウエイトトレーニングの時間に通常行
Table2 Weight training program in study 2 .

\begin{tabular}{lll}
\hline Exercise & reps/load & set \\
\hline Depth jump $-45 \mathrm{~cm}$ box ${ }^{-}$ & $3 \mathrm{reps}$ & $3 \mathrm{set}$ \\
Squat & $5 \mathrm{reps} / 8 \mathrm{RM}$ & $3 \mathrm{set}$ \\
Bench press & $5 \mathrm{reps} / 8 \mathrm{RM}$ & $3 \mathrm{set}$ \\
Lat pull down & $10 \mathrm{reps} / 10 \mathrm{RM}$ & $3 \mathrm{set}$ \\
Dumbbell pullover & $10 \mathrm{reps} / 10 \mathrm{RM}$ & $2 \mathrm{set}$ \\
Side lunge & $10 \mathrm{reps} / 10 \mathrm{RM}$ & $2 \mathrm{set}$ \\
Calf raises & $20 \mathrm{reps} / 20 \mathrm{~kg}$ & $2 \mathrm{set}$ \\
\hline & & rest: $60-90 \mathrm{sec}$
\end{tabular}

っている種目に加えて, DJを行わせた． DJ は 45 $\mathrm{cm}$ 高の台を使用し, 手を腰にあて, 台から飛び降 り, 着地後, 両脚で素早く切り返して真上に出来 るだけ高く跳び上がらせた. その際, 着地してか ら跳び上がるまでの接地時間は出来るだけ短くす るように指示した. なお, この期間におけるウエ イトトレーニングは, 主に筋力維持を目的とした プログラムを実施した（表 2). ウエイトトレー ニングの条件設定にあたっては, 日本トレーニン グ指導者協会のガイドライン（有賀，2008）を参 考にし，それぞれトレーニング量と強度を設定し た. 負荷設定は RM 法を用い, トレーニング効 果に応じて, 可能な限り負荷を漸増するように指 示した. 1 回のトレーニングの時間は 60-90 分 であり, 週 2 回の頻度で実施した. DJ は, 神経 系の機能改善や高度なテクニックが要求されるた め, プログラムの前半に疲労の少ないタイミング で実施した。 なお，トレーニングによる適応も考 慮し, ウエイトトレーニングが 2 日連続にならな いような日程にした。 その他に, バレーボール の技術・戦術練習を週 5 回（1 回 1-2 時間程度） 実施した。

\section{C. 測定および評価方法}

トレーニング効果の確認および評価するため, 下肢筋力と各種跳躍能力をトレーニング前（以 下「Pre」と略す), トレーニング後（以下「Post」 と略す）で比較し評価した。

下肢筋力の評価として, 両脚での SQ の最大挙 上重量（以下，1RM）から体重を除した值であ る SQ1RM 体重比を測定した. Baker et al.（1999） 
は，最大筋力，パワーの関係を調べるためには， 体重当たりの相対值の方が，絶対值よりも意味が あると報告していることから，本研究における SQ の評価についても，絶対值ではなく体重に対 する 1RM の相対值を用いた. SQ の 1RM 測定は, 膝関節の角度が $90^{\circ}$ になるところまでしゃがみ込 み，腰背部の姿勢を維持したまま再び立位姿勢を 維持することができた場合を成功試技とした．日 常のトレーニングで用いる重量および反復回数を 目安にして，重量を漸増させながら 3-4 セット のウォームアップを行い, その後, 1RM と思わ れる重量を用いて試技を行った。この試技の挙上 に成功した場合には，2.5kg ずつ増量しながら試 技を継続し，挙上に失敗した試技の直前の試技に おける挙上重量を 1RM の記録とした。

跳躍能力の評価として, バレーボールの代表的 な動作であるスパイクジャンプ（以下「SPJ」と 略す）と垂直跳び（以下「CMJ」と略す）の跳躍 高, 短い接地時間で高く跳ぶ跳躍であるリバウ ンドジャンプ（Rebound Jump：以下「RJ」と略 す）の跳躍高と接地時間を測定し, 跳躍高を接地 時間で除することによって得られるリバウンドジ ヤンプ指数（以下「RJ-index」と略す）を算出し た. SPJ の最高到達点および指高（直立した姿勢 から腕を頭上にできるだけ高く挙げ，床から指先 までの高さ）は，バーティカルジャンプ測定スケ ール（ヤードスティック， swift社製）を用いて 測定した. 3 歩の助走での SPJ を全力で行った際 の指先の高さを最高到達点とし，最高到達点から 指高を減じた值を SPJ 跳躍高とした。CMJ およ び RJ-index は，マットスイッチ計測システム（マ ルチジャンプテスタ，DKH 社製）を用いて測定 した. CMJ は, 直立姿勢から手を腰にあて, 脚 の反動を用いて全力で跳躍するように指示した。

RJ-index は，直立姿勢から手を腰にあてたまま， RJを 5 回連続で行い, 最も高い RJ-index の值を 採用した. RJ は, 膝関節を曲げすぎないようにし， できるだけ接地時間を短く，かつできるだけ高い 跳躍を行うように指示した.いずれの跳躍測定に ついても, 十分なウォームアップを行った後, 測 定は 2 回ずつ行い，值が高い方を代表值とした.

\section{D. 統計処理}

測定值はすべて平均值士標準偏差で示した. 対象者を $\mathrm{CMJ}$ の跳躍能力と $\mathrm{RJ}$ の跳躍能力の優劣 によって跳躍タイプを 2 群に分け，トレーニング 前後の測定值を対応のある $\mathrm{t}$ 検定によって比較し た. 跳躍パフォーマンス（SPJおよび CMJ）につ いては，介入前後抢よびタイプの効果について， 繰り返しのある 2 要因の分散分析を用いて解析し た。いずれの統計処理も有意性は危険率 $5 \%$ 未満 とした.

\section{III 結 果}

\section{A. 最大筋力向上を目的としたウエイトトレーニン グの効果に関する跳躍タイプ別検討（課題 1）}

国内トップレベル男子バレーボール選手 202 名 を対象とした先行研究（岡野ほか，2017）にお ける，CMJ（x）と RJ-index（y）の関係の回帰式 $(\mathrm{y}=1.99 \mathrm{x}+0.9952)$ をもとに算出された計算 式（2x-y + 1) により，正の值を示す場合は RJindexに対して CMJが優れた值を示すタイプ(CMJ 型， $\mathrm{n}=8$ )，負の值を示す場合は CMJ に対して RJ-index が優れた值を示すタイプ（RJ 型， $\mathrm{n}=5)$ と 2 群に対象チームの選手を分類した（図 1).

表 3 に CMJ 型および RJ 型のトレーニング前 後における各測定項目の変化を示した。体重は, RJ 型，CMJ 型ともに経時的変化は認められなか った. SQ1RM/BW は，RJ型，CMJ 型ともに有意

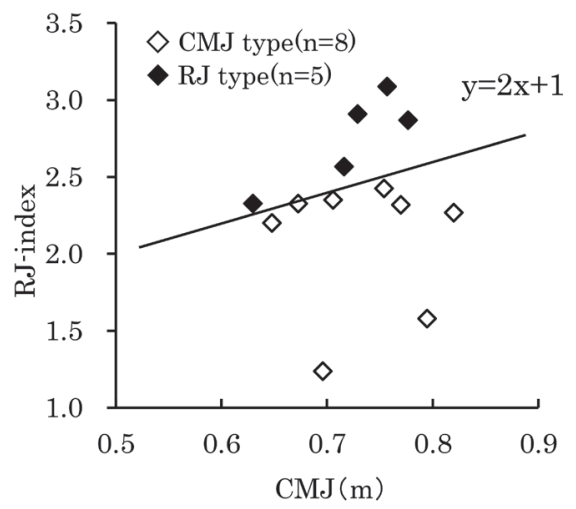

Figure 1 Dividing subjects into two types depended on their jump characteristics in study 1 . 
Table3 Changes in Body weight, SQ1RM/BW, Jumping abilities and SPJ in study 1.

\begin{tabular}{lcccc} 
& \multicolumn{2}{c}{ CMJ type } & \multicolumn{2}{c}{ RJ type } \\
\cline { 2 - 5 } & Pre & Post & Pre & Post \\
\hline Body weight (kg) & $88.1 \pm 14.5$ & $88.2 \pm 14.8$ & $78.5 \pm 4.5$ & $79.1 \pm 5.0$ \\
SQ1RM/BW & $2.05 \pm 0.23$ & $2.22 \pm 0.27^{* *}$ & $2.21 \pm 0.22$ & $2.31 \pm 0.24^{*}$ \\
SPJ (m) & $0.82 \pm 0.08$ & $0.84 \pm 0.09$ & $0.84 \pm 0.07$ & $0.93 \pm 0.03^{*}$ \\
CMJ (m) & $0.73 \pm 0.06$ & $0.78 \pm 0.06^{*}$ & $0.72 \pm 0.06$ & $0.80 \pm 0.05^{*}$ \\
RJ-index & $2.09 \pm 0.43$ & $2.12 \pm 0.31$ & $2.75 \pm 0.30$ & $2.45 \pm 0.32$ \\
\hline
\end{tabular}

Means \pm SDs are shown. *: $\mathrm{p}<0.05 ; * *: \mathrm{p}<0.01$; significant differences vs. Pre
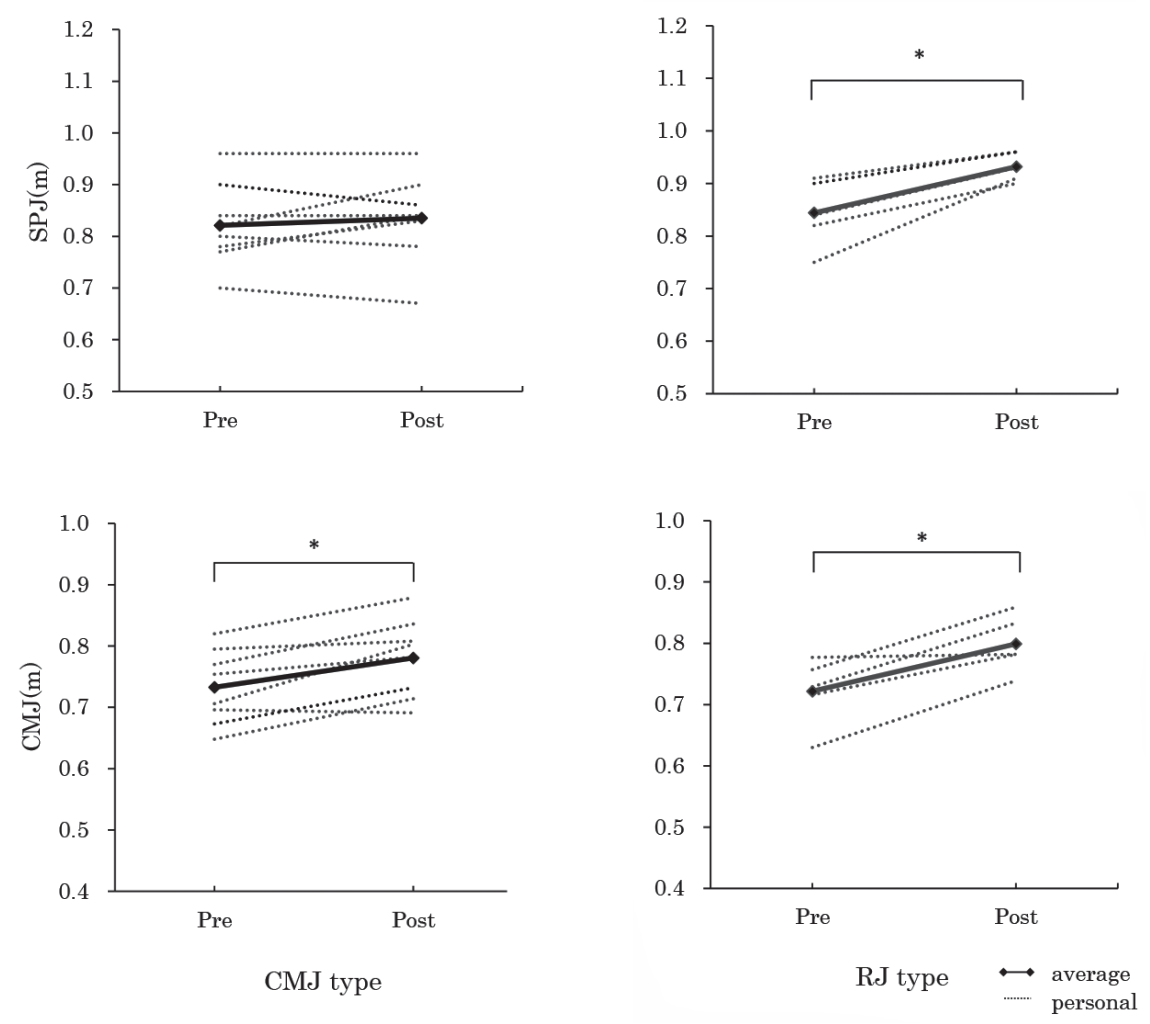

Figure 2 Changes in jumping performance in study 1.

$*: \mathrm{p}<0.05$; significant different between period

な記録の向上 $(\mathrm{RJ}$ 型 $: p<0.05, \mathrm{CMJ}$ 型: $p<$ 0.01, ）が認められた. 図 2 に跳躍パフォーマン スの経時的変化 (平均值および個人) を示した.

SPJ は, CMJ 型は経時的変化は認められなかった が，RJ型において有意な記録の向上 $(p<0.05)$ が認められ, CMJ は, CMJ 型, RJ 型ともに有 意な記録の向上 $(p<0.05)$ が認められた. RJindex は, RJ 型, $\mathrm{CMJ}$ 型ともに経時的変化は認め られなかった. 分散分析の結果, 跳躍パフォーマ
ンスはSPJにおいてトレーニング前後とタイプの 交互作用が有意であった（図 3).

\section{B. バリスティック運動の遂行能力向上を目的と したプライオメトリクスの効果に関する跳躍 タイプ別検討（課題 2)}

課題 1 と同様に, 国内トップレベル男子バレー ボール選手の CMJ（x）とRJ-index（y）の関係 の回帰式 $(\mathrm{y}=1.99 \mathrm{x}+0.9952)$ をもとに算出さ 

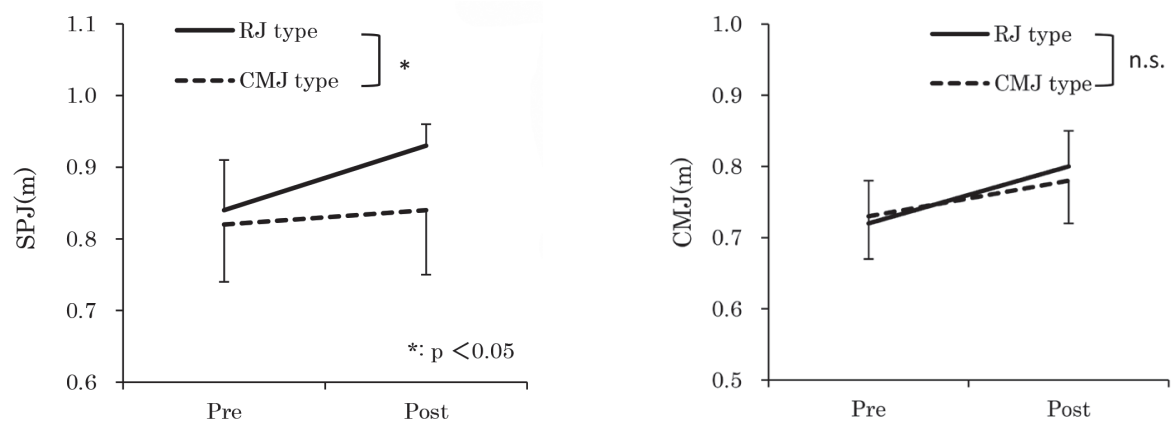

Figure 3 Two-way repeated measures ANOVA (type $\times$ period) was applied to compare the effects between the RJ type and CMJ type: study 1 .

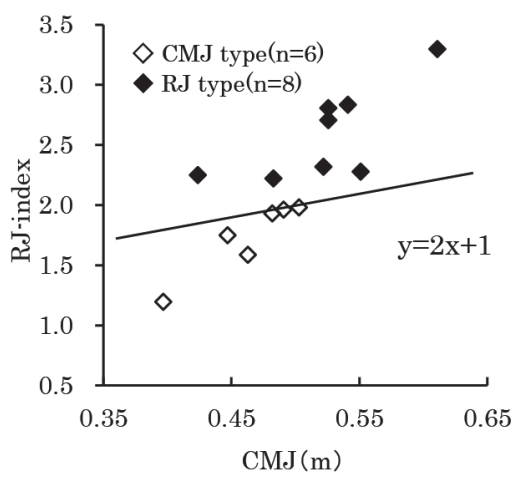

Figure 4 Dividing subjects into 2 types depended on their jump characteristics in study 2 .

れた計算式 $(2 \mathrm{x}-\mathrm{y}+1)$ により，正の值を示す 場合は CMJ 型 $(\mathrm{n}=6)$ ，負の值を示す場合は RJ 型（n=8）と2 群に対象チームの選手を分類し た (図 4).

表 4 に CMJ 型および RJ 型のトレーニング前後 における各測定項目の変化を示した。体重および $\mathrm{SQ1RM} / \mathrm{BW}$ は, RJ 型, CMJ 型ともに経時的变化
は認められなかった. 図 5 に跳躍パフォーマンス の経時的変化（平均值および個人）を示した。 SPJ は, CMJ 型は有意な記録の向上 $(p<0.05)$, RJ 型において有意な記録の低下 $(p<0.05)$ か 認められ，CMJ は，RJ型， CMJ 型ともに経時的 変化は認められなかった. RJ-index は, RJ 型に おいて有意な記録の低下 $(p<0.05), \mathrm{CMJ}$ 型は 有意な記録の向上 $(p<0.05)$ が認められた。そ の際の RJ における跳躍高は RJ 型, CMJ 型とも に経時的変化は認められなかったが，接地時間 は RJ 型において有意な増加 $(p<0.05)$ が認め られた。分散分析の結果, 跳躍パフォーマンスは SPJ, CMJ ともにトレーニング前後とタイプの交 互作用が有意であった（図 6).

\section{IV 考 察}

本研究では, バレーボール選手に要求される SPJ の跳躍能力向上を目的としたトレーニングに

Table4 Changes in Body weight, SQ1RM/BW, Jumping abilities and SPJ in study 2.

\begin{tabular}{lcccc} 
& \multicolumn{2}{c}{ CMJ type } & \multicolumn{2}{c}{ RJ type } \\
\cline { 2 - 5 } & Pre & Post & Pre & Post \\
\hline Body weight (kg) & $75.6 \pm 8.9$ & $76.3 \pm 9.9$ & $72.7 \pm 7.1$ & $73.4 \pm 7.0$ \\
SQ1RM/BW & $1.79 \pm 0.20$ & $1.82 \pm 0.20$ & $1.81 \pm 0.11$ & $1.83 \pm 0.10$ \\
SPJ (m) & $0.80 \pm 0.08$ & $0.85 \pm 0.07^{*}$ & $0.77 \pm 0.08$ & $0.74 \pm 0.09^{*}$ \\
CMJ (m) & $0.46 \pm 0.04$ & $0.49 \pm 0.02$ & $0.52 \pm 0.05$ & $0.50 \pm 0.06$ \\
RJ-index & $1.74 \pm 0.31$ & $2.07 \pm 0.36^{*}$ & $2.59 \pm 0.40$ & $2.21 \pm 0.50^{*}$ \\
RJ (height: m) & $0.33 \pm 0.06$ & $0.36 \pm 0.04$ & $0.42 \pm 0.05$ & $0.39 \pm 0.07$ \\
RJ (contact time: sec ) & $0.18 \pm 0.02$ & $0.18 \pm 0.03$ & $0.16 \pm 0.02$ & $0.18 \pm 0.01^{*}$ \\
\hline
\end{tabular}

Means \pm SDs are shown. ${ }^{*}$ : $<<0.05$; significant differences vs. Pre 

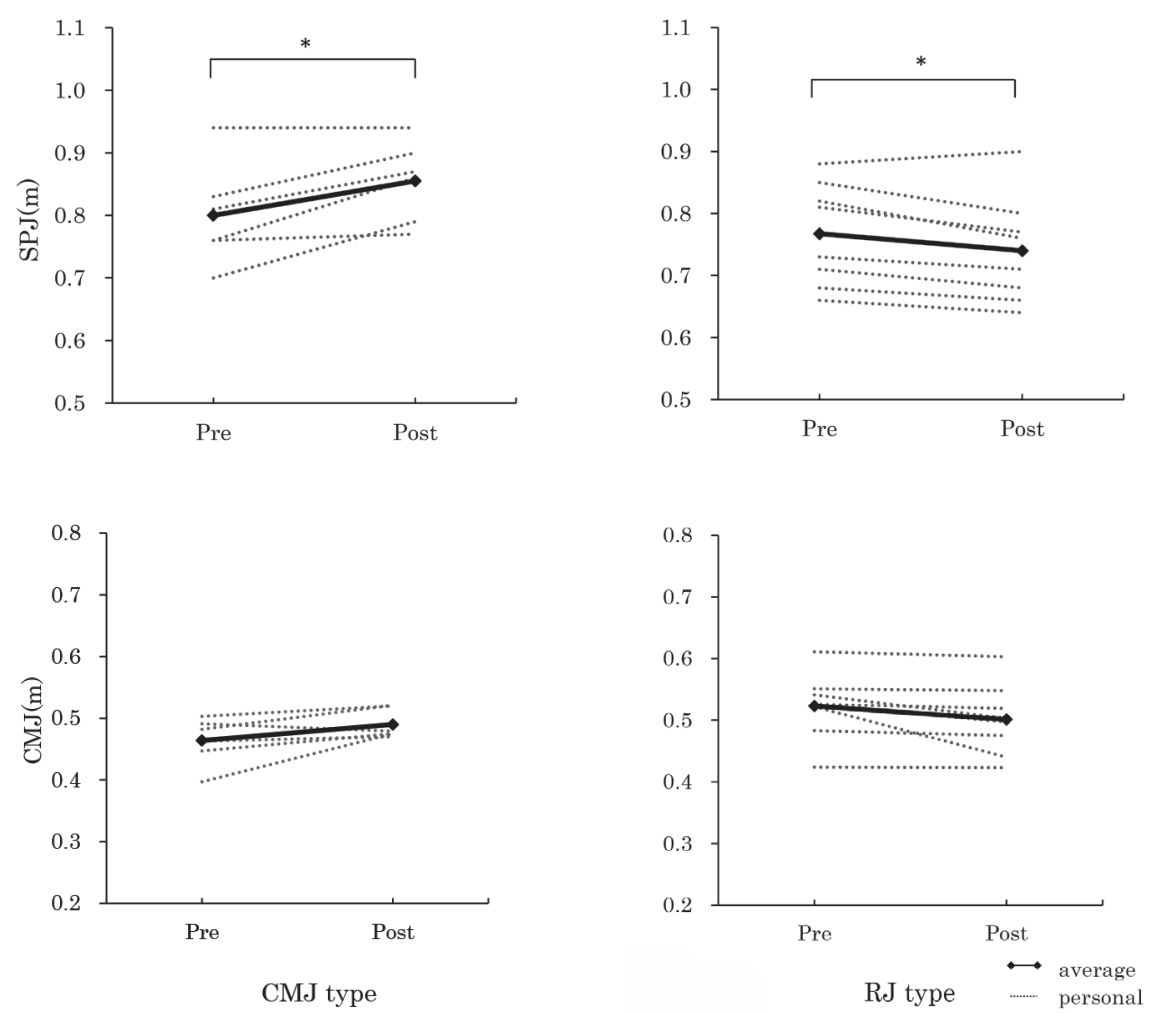

Figure 5 Changes in jumping performance in study 2. *: $\mathrm{p}<0.05$; significant different between period
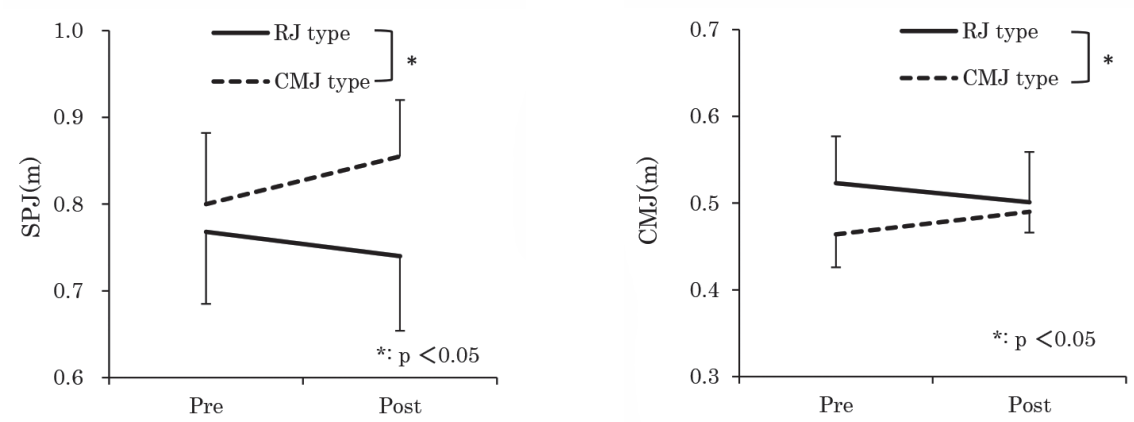

Figure 6 Two-way repeated measures ANOVA (type $\times$ period) was applied to compare the effects between the RJ type and CMJ type: study 2 .

ついて,より大きな力積を獲得する能力とバリス ティックな運動を遂行する能力の優劣から, 選手 個々の跳躍タイプに応じたトレーニング方法を明 確にするための基礎的知見を得ることを目的とし た. そこで, より大きな力積を獲得する能力とバ リスティックな運動を遂行する能力の指標とし て，それぞれ代表的な跳躍項目である $\mathrm{CMJ} の$
跳躍高とRJ-index を計測した. CMJ とRJ-index の関係について, 先行研究 (Hennessy and Kilty, 2001 ; Young et al., 1995 ; 図子・高松, 1995）で は CMJ と DJ-index との相関係数は小さいことか ら, 両者はそれぞれ異なった能力であると報告さ れている.つまり, 個人内では CMJ の跳躍能力 に対して RJ の跳躍能力が相対的に優れている者 
と劣っている者とが存在していることを示してい る（遠藤ほか，2007）。そこで，岡野ほか（2017） による，国内トップレベル男子バレーボール選手 202 名を対象とした先行研究で算出された CMJ とRJ-indexの関係における回帰式により，選手 を跳躍能力別にタイプ分けし（図 1，4），それぞ れの選手が同一のトレーニングを実施した際の効 果をタイプ別に検証した.これらの検証によって, 選手個々の体力特性に応じたバレーボール選手に おける跳躍力向上を目的としたトレーニング方法 を明確にするための基礎的知見を得ることが出来 るのではないかと考えられる.

\section{A. 最大筋力向上を目的としたウエイトトレーニン グの効果に関する跳躍タイプ別検討(課題 1)}

最大筋力は, 様々なスポーツの動作におい て，パワー発揮能力を高めるための基盤となる (Gadeken, 1999). また, より最大筋力の高いア スリートほど大きなパワーを発揮できることが 報告（Baker, 2001; Stone et al., 2002）されており, パワー発揮能力を高めるためには, 最大筋力を 高めていく必要がある. 適切に計画されたウエ イトトレーニングプログラムを行うことで，よ り大きな力を発揮することが可能となり，下肢 の最大筋力の向上と並行して垂直跳びのパフォ ーマンスも向上することが明らかになっている (Hedrick, 1996). さらに, ウエイトトレーニング の代表的な種目である SQ は, 垂直跳びと SQ 動 作における立ち上がり時のパワーおよび最大筋力 との間に相関関係があるといわれている（福永ほ か，1991；金久，1990）。本研究においても，最 大筋力向上を目的としたウエイトトレーニングに より, SQ1RM/BW は RJ 型, $\mathrm{CMJ}$ 型ともに有意 な記録の向上 $(\mathrm{RJ}$ 型 : $p<0.05, \mathrm{CMJ}$ 型 $: p<$ 0.01）が認められ，それに伴って CMJ も RJ 型, CMJ 型ともに有意な記録の向上 $(p<0.05)$ が 認められた.

一方, SPJにおけるトレーニング前後の変化を みると, $\mathrm{RJ}$ 型は有意な記録の向上 $(p<0.05)$ が認められたが, CMJ 型は経時的変化は認めら れなかった.これまでSPJ の跳躍高を高めるた
めには, CMJ, RJ それぞれの能力を高める必要 があることが報告されている（岡野ほか，2016； Sheppard et al., 2008）が, 岡野ほか（2017）は先 行研究において, より高いレベルにあるバレーボ ール選手は, RJ の要素がより重要である可能性 を示唆している. 本研究において, RJ-index に対 して CMJ が優れた值を示すタイプ（CMJ 型）の 選手が，最大筋力向上を目的としたトレーニン グにより最大筋力に有意な向上が認められても, SPJ に変化は認められないことが明らかになっ た.

SPJ は助走によって生み出された水平速度を効 率的に垂直速度に変換することによって, CMJ よりも 12-19 cm 高い跳躍高を獲得すること を可能にする（セリンジャー・アッカーマン， 1993).さらに, Sheppard et al.（2008）は, ス パイクジャンプの跳躍高は $\mathrm{CMJ}$ と比較して，お よそ 17一20 cm 高かったことを示している。ま た，SPJについてバイオメカニクス的に研究した 報告では, 踏切時の膝関節最大屈曲角度は利き 足が約 90-116 度, 非利き足が約 125〜140 度 であったこと（福原ほか, 1982 ; 増村・阿江, 2007 ; Tilp et al., 2008), 膝関節の伸展時間は, 利 き足で 0.133 秒，非利き足で 0.106 秒（Tilp et al., 2008）であったと述べている．また，SPJ の踏切 時における左右の脚を運動力学的に比較した研究 （Lawson et al., 2006）では，平均床反力および下 肢 3 関節の平均関節モーメントは非利き脚に比べ 利き脚の方が有意に高かったと報告されている.

このように, SPJ の踏切時における関節角速度, 関節角度，接地時間あるいは伸展時間など左右 の足で異なることが報告されており，SPJ と CMJ は同じ跳躍種目であっても運動様式が異なる運動 であるといえる.さらに，元々 RJ-index に対し て CMJ が優れた值を示す CMJ 型の選手は，最大 筋力が向上しても，SPJにおけるより大きな力積 を獲得する能力に関しては，変化がみられなかっ たことも考えられる，そのため， CMJ 型の選手 は最大筋力向上を目的としたトレーニングによっ て, 最大筋力は向上したものの, SPJ の跳躍高に は変化が認められなかったことが推察される. 
このように本研究では, 先行研究と同様に最大 筋力が向上することにより, すべての選手におい て CMJ が向上することが認められたが, バレー ボール競技における特異的な跳躍種目である SPJ において，RJ型には向上が認められたが， CMJ 型は変化が認められなかったことから, 跳躍タイ プによってトレーニング効果が異なることが示 唆された. しかし, 本研究では SPJ, CMJ および RJ の力積や関節モーメント等の測定は行ってい ないため, 上記の課題を明らかにしていくために は, 今後, さらに詳細な検証が必要であると考え られる。

\section{B. バリスティック運動の遂行能力向上を目的と したプライオメトリクスの効果に関する跳躍 タイプ別検討（課題 2)}

課題 2 における主となるトレーニング種目はプ ライオメトリクスであり, ウエイトトレーニング による影響を出来る限り排除するため，この期間 のウエイトトレーニングのプログラムは筋力維持 を目的とした負荷設定とした. その結果, 本研 究における 8 週間のプライオメトリクスによっ て, RJ 型, CMJ 型のいずれのタイプも SQ1RM/ BW に有意な変化は認められなかった. 最大筋力 が向上することにより, 垂直跳びのパフォーマン スも向上することが明らかになっている (Hedrick, 1996). 本研究においても, RJ 型, CMJ 型ともに SQ1RM/BW に有意な変化は認められなかったこ とから, CMJ も経時的変化が認められなかった ことが推察される.

SPJ 跳躍高およびRJ-index におけるトレーニン グ前後の変化をみると, RJ 型は有意な記録の低 下が認められ, CMJ 型は有意な記録の向上が認 められた. Sheppard et al. (2008) は, SPJ と垂直 跳び, DJ の跳躍高, スクワット $1 \mathrm{RM}$ およびスク ワットジャンプ時の発揮パワーとの関係について 検討し, SPJ の跳躍高と相関が高かったのは, 垂 直跳びと DJ であったと報告している．このこと から, SPJ には垂直跳びのようなより大きな力積 を獲得する能力と合わせて, DJ のようなバリス ティックな運動を遂行する能力も必要であると考
えられる.これらの両者をそれぞれ高める方法と して, ウエイトトレーニングやプライオメトリ クスといった個別のトレーニングも挙げられる が, バレーボール選手はそれまでの練習や試合に よって，これらの特異的な能力がそれぞれ向上 したことも考えられる．また，遠藤ほか（2007） は, CMJ とRJ-indexの関係において, CMJ と RJ-index は経年的に発達するが, 個人内における 両者の跳躍能力は必ずしも対応しながら発達する わけではなく, 特にスポーツ選手は高度に専門化 された競技種目に特異的なトレーニングを積むこ とによって, 跳躍能力の個人差がさらに拡大して いくことを示唆している.さらに，バレーボール 選手における各種跳躍能力をポジション別で比較 を行った先行研究（岡野ほか，2016）において, ミドルブロックのポジションの選手における攻撃 （スパイク）はクイック攻撃が中心であり, 短い ホップで速いテイクオフにつながる 1 歩か 2 歩の 助走が必要といわれており（セリンジャー・アッ カーマンブルント, 1993), 比較的長時間の SSC 運動による力発揮をより行いながら跳躍を行う必 要があること, 一方のウイングスパイクのポジシ ヨンの選手は, セッターから配球されるトスの高 さがミドルブロックの選手と比較して高く（橋 原ほか, 2009 ; 金ほか, 1998), 十分な助走をと り，その助走スピードを利用しバリスティックな SSC 運動をより行いながら跳躍を行っていること が考えられると報告している．これらのことから RJ 型の選手は，これまで行ってきたバレーボー ルの専門的な技術練習や跳躍トレーニングによっ て, 高い SSC 能力が養われ, より大きな力積を 獲得する能力とバリスティックな運動を遂行する 能力をバランス良く使われていた可能性が考えら れる. 本研究においても, RJ 型にはウイングス パイカーのポジションの選手が多く分類されてい た. その RJ 型の選手は，プライオメトリクスの 導入 8 週間後に RJ の接地時間が長くなり, それ に伴って RJ-index が低下し, SPJ の跳躍高も有意 に低下している. バレーボール競技の動作にはス パイクやブロックなど多くの跳躍動作が含まれて おり, トップレベル男子バレーボール選手におけ 
る練習や試合の中では，守備専門のポジションで あるリベロを除き，1 試合平均 50-150 回と高頻 度で跳躍が行われている（岡野・谷川, 2016）。 RJ 型の選手はバレーボールの練習時において, バリスティックな SSC 運動をより行いながら多 くの跳躍を行っていることが考えられ, 通常の練 習と並行して行う DJトレーニングはオーバート レーニングとなり，その結果，接地時間が長くな りRJ-indexの低下に繋がったことが要因として 考えられる. しかし，同様のトレーニングを行っ た $\mathrm{CMJ}$ 型の選手においては, RJ の接地時間に変 化が見られなかったことから, 跳躍遂行能力タイ プと疲労との関係については，今後，詳細に検討 していく必要がある.

一方， $\mathrm{CMJ}$ 型の選手は，これまで行ってきた バレーボールの専門的な技術練習や跳躍トレーニ ングによって，より大きな力積を獲得する能力が バリスティックな運動を遂行する能力と比べ養わ れていたが, 本研究で行ったプライオメトリクス により，さらにバリスティックな運動を遂行する 能力も高まることによって，SPJ が向上したこと が推察される. 課題 1 において RJ 型の選手がウ エイトトレーニングにより CMJ の能力を向上さ せることによって SPJ 跳躍高が向上した結果と同 様に, 課題 2 においても $\mathrm{CMJ}$ 型の選手がプライ オメトリクスにより RJ の能力を向上させること によって SPJ 跳躍高が向上することが明らかにな った。これらの結果から, SPJ 能力には CMJ と RJ の能力の相補的な関係が存在していることを 理解し, SPJ 跳躍高を目的としたトレーニングを 行う際には, 選手の跳躍タイプに応じてトレーニ ング方法を考慮していく必要があると考えられ る.

\section{C. トレーニング学における事例研究の重要性}

これまでのトレーニング効果を実証する研究の 多くは，ある仮説を設定しそれを検証するために トレーニング群とコントロール群に分けた上で, 一定の期間に渡ってトレーニング負荷を与え，ト レーニング効果の相違を統計的手段を使って検 定するという方法が一般的である（田路・金子,
2002 ; 図子, 2013)。しかし, 本研究では, 全対 象者に目的となるトレーニングを実施し効果を検 証した結果，同一のグループ内においても様々な タイプが内在し，同じようにトレーニングを行っ ても，トレーニング効果が異なる可能性があるこ とが明らかになった。このことは，トレーニング 処方において個別性を考慮することも重要である ことを示しており，このような事象を詳細に検証 していくためには，事例研究が重要であると考え られる. 西條（2008）は，たとえ研究対象が 1 事 例であっても，現象の見え方が変わるような視点 で提示できたり，よりよい実践につながるモデル を構成できれば，価值ある事例研究になりうると 述べている．実際のトレーニング現場において， 選手個々の特性は多岐にわたっており，従来の対 象者を均一化して得られたトレーニング効果の結 果からだけでは課題解決にむけた示唆を得ること が困難な場合も少なくない，科学的研究で導き出 された知見に，これら事例研究を蓄積し整理統合 された多数の知見を融合して多面的に捉えること により，個々の特性に応じたトレーニングに関す る一般理論の確立が可能となり，現場に即した有 用な知見となると考えられる.

\section{V まとめ}

本研究では, バレーボールにお打るスパイクジ ヤンプというパフォーマンスに着目し, 男子バレ 一ボールチームにおいて跳躍遂行能力タイプの異 なる選手を分類し，それぞれトレーニング（ウ エイトトレーニング, プライオメトリクス）を 実施した際のトレーニング効果をタイプ別に検 証した。より大きな力積を獲得する能力に優れ た CMJ 型の選手は，最大筋力向上を目的とした ウエイトトレーニングによって，SPJ の跳躍高に は有意な変化は認められなかったが，プライオメ トリクスによって，有意な向上が認められた。一 方，バリスティックな運動を遂行する能力に優れ た RJ 型の選手は，最大筋力向上を目的としたウ エイトトレーニングによって, SPJ の跳躍高は有 意な向上が認められたが，プライオメトリクスに 
よって, 有意な低下が認められた.このように, 同一のトレーニングを実施した際, 跳躍遂行能力 タイプに応じてトレーニング効果が異なることが 明らかになり, バレーボール選手に対して跳躍パ フォーマンス向上を目的としたトレーニングを処 方する際には, 選手個々の跳躍遂行能力タイプを 考慮してトレーニング種目を選択する必要がある ことが示唆された. さらに, 本研究で用いた跳躍 測定の項目は比較的利用しやすいと考えられるた め, 個々の能力を測定評価し, 個人の体力特性を 考慮したトレーニング選択を行うための 1 つの指 標になりうると考えられる.

\section{文 献}

有賀誠司・成田明彦・積山和明 ・ 湯浅康弘 ・生方謙 - 恩 田哲也・中村豊・寺尾保（2000）大学女子バレーボー ル選手におけるウエイトトレーニングの長期的実施に 伴う形態及び体力の変化. 東海大学スポーツ医科学雑 誌, $12: 42-53$.

有賀誠司（2008）筋力トレーニングのプログラム作成. 日本トレーニング指導者協会編著, トレーニング指 導者テキスト実践編. ベースボール・マガジン社, pp.38-51.

浅井正仁（2001）バレーボールゲームの得点に関するゲ 一ム分析的研究一ラリーポイント制における得点構 成及び連続得点について一, 大阪体育大学紀要, 32 : 13-24.

Baker, D. (2001) Comparison of upper-body strength and power between professional and college aged rugby league players. J. Strength Cond. Res., 15: 30-35.

遠藤俊典・田内健二・木越清信・尾縣貢（2007）リバウ ンドジャンプと垂直跳の遂行能力の発達に関する横断 的研究. 体育学研究, $52: 149-159$.

福原祐三・朽堀伸二 ・ 都沢凡夫 - 石島繁 - 阿江通良 - 橋 原孝博 - 横井孝志 - 矢島忠明 - 遠藤俊郎 - 池上寿伸 . 岡内優明・吉田雅行・小山勉（1982）'82 年日米対抗 女子バレーボールに拝ける一流選手のスパイク動作に 関する事例的研究. 昭和 57 年度日本体育協会又ポー ツ科学研究報告, $2: 331-341$.

福永哲夫 - 松尾彰文 - 安部孝 - 川上泰雄 - 沼沢秀雄 深代千之（1991）種目別スポーツ競技力評価方法の開 発一バレーボール競技の場合一、スポーツ医・科学, $5(2): 47-54$.

Gadeken, S.B. (1999) Off-season strength, power, and plyometric training for KansasState volleyball. Strength Cond. J., 21(6): 49-55.
橋原孝博・吉田康成・吉田雅行（2009）バレーボール男 子世界トップレベルチームの戦術プレーに関する研 究一2006 年男子世界選手権におけるブラジルおよび イタリアチームの分析一. バレーボール研究, 11(1) : 12-18.

Hedrick, A. (1996) The vertical jump: a review of the literature and a team case study. Strength Cond. J.,18(7): 7-12.

Hennessy, L. and Kilty, J. (2001) Relationship of the stretchshortening cycle to sprint performance in trained female athletes. J. Strength Cond. Res., 15(3) : 326-331.

星川佳広・菅野淳・涉川賢一（2006）サッカーに扔ける 体力の研究一これからの展望一.フットボールの科学, $1: 10-17$.

金久博昭（1990）スポーツ選手トレーニングにおけるジ ヤンプ・パフォーマンス向上のためのトレーニング. Japanese journal of sports sciences, 9(4) : 202-209.

金致偉・佐賀野健・橋原孝博・西村清巳（1998）世界卜 ップ男子バレーボールチームのコンビネーション攻撃 一1995 年ワールドカップイタリア対日本戦の映像分 析一. スポーツ方法学研究, 11(1) : 25-35.

Lawson, B.R., Stephens II, T.M., DeVoe, D.E., and Reiser II, R.F. (2006) Lower-extremity bilateral differences during step-close and no-step countermovement jumps with concern for gender. J. Strength Cond. Res., 20(3) : 608-619. 増村雅尚・阿江通良（2007）特集 跳躍動作のバイオメ カニクスバレーボール選手のスパイクジャンプ. 体 力の科学, 57(7) : 521-527.

都沢凡夫・枋堀申二・福原祐三 (1995) バレーボールの サイドアウトに関する研究(5). 筑波大学運動学研究, 11 : 63-78.

都沢凡夫・塚本正仁 (1999) スパイク理論に関する研 究一フォアスイングについて一. バレーボール研究, $1(1): 9-15$.

岡野憲一・谷川聡 (2016). バレーボール国内男子トッ プリーグの試合中における跳躍頻度に関する研究. バ レーボール研究, 18(1) : 27-31.

岡野憲一・山中浩敬・内藤景・谷川聡 (2016) エリート 男子バレーボール選手における身長と跳躍能力に関す る研究. コーチング学研究, 29(2) : 149-159.

岡野憲一・山中浩敬・九鬼靖太 - 谷川聡 (2017) 伸張一 短縮サイクル運動の遂行能力からみたトップレベル男 子バレーボール選手の跳躍パフォーマンスの特性. 体 育学研究, 62(1) : 105-114.

西條剛央 (2008) ライブ講義・質的研究とは何か SCQRM アドバンス編. 新曜社, pp.102-110.

坂井和明 - 伊藤竜兵 - 大高敏弘 - 高松薰 (2006) 球技又 ポーツ競技者における個別性の原則を考慮した体力卜 レーニングの効果. 体育学研究, $51: 21-32$. 
セリンジャー・アッカーマンブルント:都沢凡夫訳(1993) チーム構成. 朽堀申二監, セリンジャーのパワーバレ 一ボール. ベースボール・マガジン社, pp.29-32.

Sheppard, J. M., Cronin, J. B., Gabbett, T. J., McGuigan, M. R., Etxebarria, N., and Newton, R. U. (2008) Relative importance of strength, power, and anthropometric measures to jump performance of elite volleyball players. J. Strength Cond. Res., 22(3): 758-765.

Stone, M. H., Moir, G., Glaister, M., and Sanders, R. (2002) How much strength is necessary? Phys Ther Sport, 3: 8896.

田路秀樹・金子公宥（2002）筋パワーに及ぼす複合トレ 一ニングの効果：特に力一速度関係に及ぼす静的及び 動的筋力トレーニングの影響について．トレーニング 科学, 13(3) : 127-136.

Tilp, M., Wagner, H., and Muller, E. (2008) Differences in 3D kinematics between volleyball and beach volleyball spike movements. Sports Biomechanics, 7(3) : 386-397.

Young, W. B., Pryor, J. F., and Wilson, G. J. (1995) Effect of instructions on characteristics of countermovement and drop jump performance. J. Strength Cond. Res., 9(4): 232236.

図子浩二・高松薰（1995）バリスティックな伸張 - 短縮 サイクル運動の遂行能力を決定する要因一筋力および 瞬発力に着目して一. 体力科学, $44: 147-154$.

図子浩二（2006）バスケットボール選手におけるプライ オメトリックスがジャンプとフットワーク能力および パス能力に及ぼす効果. 体力科学, 55 : 237-245.

図子浩二（2013）筋力・パワー集中負荷方式およびプラ イオメトリクス強調方式のトレーナビリティに関する トレーニング学的研究〜跳躍競技者のプレシーズンに おけるトレーニング経過を手がかりにして〜。陸上競 技学会誌, 11(1)：39-49.

$$
\left(\begin{array}{l}
2017 \text { 年 } 6 \text { 月 } 16 \text { 日受付 } \\
2017 \text { 年 } 10 \text { 月 } 23 \text { 日受理 }
\end{array}\right)
$$

Advance Publication by J-STAGE Published online 2017/12/20 